\title{
Etički problemi povezani s dopuštenjem uporabe moralno spornih cjepiva
}

\author{
ZORICA MAROS* \\ • https://doi.org/10.31823/d.29.3.7 • \\ UDK: 179:614.4*27-42 • Pregledni članak \\ Primljeno: 30. ožujka 2021. • Prihvaćeno: 24. rujna 2021.
}

${ }^{*}$ Izv. prof. dr. sc.

Zorica Maros, Katolički bogoslovni fakultet, Univerzitet $\mathrm{u}$

Sarajevu,

Josipa Stadlera 5,

71000 Sarajevo,

Bosna i Hercegovina, maroszorica@ gmail.com

Sažetak: Kada su šezdesetih godina prošloga stoljeća na trzišste izišla cjepiva protiv rubeole, počela je društveno-intelektualna rasprava o njihovoj eticko-moralnoj dimenziji. Naime uporaba tkiva fetusa iz namjernih pobačaja za izradu tih cjepiva cini ih moralno spornima. Premda je Crkva krajnjim korisnicima dopustila uporabu takvih cjepiva ako nema drugoga načina zaštite, odnosno ostvarenja dužnoga dobra, ipak, ta je dopuštenost izazvala, $i$ izaziva, brojne prigovore, ali i istinska nerazumijevanja i nesporazume. Može li se govoriti o moralnoj dosljednosti, integritetu, ako oni koji se oštro protive pobačaju pristaju na cjepiva čija je izrada povezana s namjernim pobačajem? Je li Crkva tim dopuštenjem kontradiktorna svom nauku, odnosno je li licemjerna? Prilog nudi teoretsko promišljanje o odredenim nesporazumima radi otklanjanja intelektualno $i$ vjernički nimalo zanemarivih nerazumijevanja.

Ključne riječi: cjepivo, Katolička Crkva, etička problematika, licemjerje, sablazan, priziv savjesti, komercijalizacija pobačaja.

\section{Uvod}

Izdvajanje fetalne stanične linije referentnoga koda WI-38 kao biološke osnove za izradu virusnih cjepiva bilo je revolucionarni napredak znanosti šezdesetih godina prošloga stoljeća. Taj se biološki materijal pokazao korisnim i sigurnim ne samo za izradu virusnih cjepiva koja su spasila živote milijuna ljudi širom svijeta nego i kao bogat materijal za brojne druge znanstvene doprinose i koristi, od brojnih znanstvenih radova do ništa manje brojnih različitih, re- 
volucionarno korisnih, istraživanja nad ljudskim stanicama. ${ }^{1}$ Ta je fetalna stanična linija dobivena iz tkiva namjerno pobačenih fetusa, što je ubrzo izazvalo oštre prigovore, protivljenja, odbijanje cijepljenja zbog prigovora savjesti. U kontekstu tih rasprava od Crkve je zatraženo službeno očitovanje o spomenutoj problematici, što je ona i uradila 2005. godine deklaracijom Moralni osvrti na cjepiva pripremljena od stanica ljudskih pobačenih fetusa te je isti stav ponovila u kraćoj izjavi 2017. godine, Bilješka o korištenju cjepiva. ${ }^{2}$ Pozivajući se na analizu moralnoga načela sudjelovanja u zlu, Deklaracija ističe da je korištenje spornim cjepivima moralno dopustivo ako nema formalnoga sudjelovanja u zlu, ako ne postoje alternativna cjepiva i ako postoji proporcionalan razlog tom korištenju. U skladu s temeljnim načelom moralnoga života zlo nikada ne smije postati predmet osobnoga izbora. To znači da je svaki oblik suradnje u zlu vjernicima nedopušten, pa i one pasivne, nedjelovanjem ili neprotivljenjem. No tolerira se udaljena posredna materijalna suradnja, pod određenim uvjetima. Jedan je od njih suprotstavljanje zlu i distanciranje od njega, što konkretno u slučaju cjepiva znači učiniti sav zakoniti pritisak kako bi se proizvodila ona koja ne će imati tu dimenziju moralne okaljanosti. ${ }^{3}$

Ista je spomenuta rasprava, makar manjega intenziteta, pokrenuta i u kontekstu novonastale pandemije bolesti COVID-19. Pojedinačni istupi u javnosti, bilo intelektualaca bilo pojedinih vjerskih skupina, pokazali su da je rasprava iz šezdesetih godina bila nepoznata našem društvenom, ali i intelektualnom okružju, kao što je bio nepoznat i službeni stav Crkve. Uslijedili su i hitni prijevodi tih stavova na hrvatski jezik, kao i najnovije očitovanje Crkve, odnosno ponovljeni postojeći stav primijenjen na cjepiva protiv bolesti COVID-19 jer se i neka od njih izrađuju uz pomoć, danas već različitih i brojnih, fetalnih staničnih linija. I taj stav ukratko ponavlja osnovne smjernice prethodnih stavova te dodaje i druge razloge sadašnjega trenutka koji dopuštaju uporabu spornih cjepiva. ${ }^{4}$

\footnotetext{
${ }^{1}$ Usp. Z. MAROS, Stav Crkve o korištenju fetalnih staničnih linija u izradi virusnih cjepiva, u: Vrhbosnensia 24(2020.)2, 404-425., ovdje 416-417.

${ }^{2}$ PONTIFICIA ACADEMIA PRO VITA, Dichiarazione. Riflessioni morali circa $i$ vaccini preparati a partire da cellule provenienti da feti umani abortiti, 5. lipnja 2005. Dostupno na: https://mednat. news/Biblio_scientifica/Elenco-Vaccini-propinati_bugiardini_schede\%20tecniche-produzione/ vaccini_preparati-da-cellule_feti_umani_abortiti.pdf (10. 9. 2020.); PONTIFICIA ACCADEMIA PER LA VITA, Nota circa l'uso dei vaccini, 31. srpnja 2017. Dostupno na: http://www.academyforlife.va/content/pav/it/the-academy/activity-academy/note-vaccini.html (29. 9. 2020.).

${ }^{3}$ Usp. PONTIFICIA ACADEMIA PRO VITA, Dichiarazione, 1-8., ovdje 3-5.; Za detaljno objašnjeno načelo sudjelovanja u zlu i njegovu primjenu na cjepiva vidi: Z. MAROS, Moralno načelo suradnje u zlu. Primjena na etički sporna cjepiva, u: Crkva u svijetu 56(2021.)2, 197-213.

${ }^{4}$ Usp. SALA STAMPA DELLA SANTA SEDE, Nota della Congregazione per la dottrina della Fede sulla moralità dell'uso di alcuni vaccini anti-Covid-19, 21. prosinca 2020. Dostupno na: https://press.vatican.va/content/salastampa/it/bollettino/pubblico/2020/12/21/0681/01591.html (12. 1.2021.).
} 
Kako smo već naznačili, moralno dopuštenje korištenja cjepivima povezanima s dobrovoljnim pobačajima izazvalo je već šezdesetih godina prošloga stoljeća brojne rasprave, a i dalje ih izaziva sudeći i prema najnovijim vijestima na različitim portalima, a i njima pripadajućim komentarima. Ovdje sažimamo neke od njih. Je li uistinu Crkva licemjerna kada osuđuje pobačaj, čak i u ekstremno tragičnim slučajevima seksualnoga nasilja, a odobrava ga onda kada ima korist od njega? ${ }^{5} \mathrm{Je} \mathrm{li} \mathrm{u}$ pitanju strašno proturječje Crkve na koje katolici nikako ne smiju pristati? ${ }^{6}$ Izazivaju li to licemjerje i proturječje Crkve određeni skandal među populacijom vjernika, skandal za koji vjernicima stoji stroga dužnost izbjegavanja u svom djelovanju? Osim toga iz privatnih rasprava s drugim ljudima kristalizira se i sljedeći prigovor: Ako se pobačaj već dogodio, nije li humanije i sa stajališta etike, a i medicinske struke, iskoristiti taj čin, izvući iz njega nešto dobro, nego zbog nekih etički načela, prividno teško objašnjivih, dopustiti propadanje tako bogatoga, znanstveno-medicinski moćnoga i zdravstveno-terapeutski obećavajućega materijala?

Iako ta pitanja, kako je već rečeno, proizlaze već iz rasprave vođene šezdesetih godina prošloga stoljeća, ipak su našoj široj javnosti i dalje nepoznata, zbog čega smo smatrali potrebnim raspraviti neka od njih u ovom prilogu. Naime spomenuto nerazumijevanje stava Crkve može istinski zbuniti, a i sablazniti određeni dio vjernika, zbog čega smatramo nužnim unijeti nešto jasnoće u spomenutu raspravu. No u isto vrijeme u prilogu upućujemo na činjenicu da spomenuto dopuštenje korištenja spornim cjepivima, iako u potpunosti opravdano i razumljivo, ipak nije toliko $u$ potpunosti lišeno određenih dvojbi da bi ga se moglo shvatiti s određenom moralnom bezbrižnošću i lakoćom, zbog čega se traži dosljedno ispunjenje svih uvjeta koje ono postavlja.

\section{Licemjerje zbog korištenja osuđivanim zlom}

Što se tiče navodnoga licemjerja Crkve koja zlo (pobačaj) dopušta kada se njime koristi (cjepivom), treba naglasiti da se prigovor uistinu pokazuje razumljivim, barem na onoj početnoj razini promišljanja, a pogotovo na nepromišljenoj reakciji na neke stavove Crkve, kako se to često u javnosti dogodi. Upravo zbog početne razine promišljanja, na kojoj se, razumljivo, u većini slučajeva i ostaje kada su u pitanju stvarnosti koje nisu predmet našega užega interesa i intelektualne zauze-

\footnotetext{
${ }^{5}$ Usp. S. MONTANARI, Tra incopmetenza e ipocrisia, 7. kolovoza 2017. Dostupno na: https:// www.stefanomontanari.net/tra-incompetenza-e-ipocrisia/ (11. 10. 2020.).

${ }^{6}$ Usp. Cjepivo za COVID-19: Cilj ne može opravdati sredstvo, 16. prosinca 2020., u: Quo Vadis Croatia. Dostupno na: https://www.quovadiscroatia.com/cjepivo-za-covid-19-cilj-ne-moze-opravdatisred-stvo/?utm_source=phpList\&utm_medium =email\&utm_campaign=Dvojbenost + cjepiva\%3F1\&utm_content=HTML (21. 12.2020.).
} 
tosti, nužno je ponuditi širi kontekst tumačenja. Konkretno u ovom slučaju nužno je naglasiti da zlo u moralnom smislu nije proizvod kao takav, odnosno samo cjepivo ili njegovo korištenje u terapeutske svrhe (što je u sebi dobro), nego su moralno zli postupci kojim se ta cjepiva dobivaju? (u svakom slučaju pobačaj kao prekid samoga početka tuđega života). Usporedbe radi, zlo medicinski potpomognute oplodnje ne leži u dobivenom djetetu, nego u samim postupcima umjetne oplodnje kao prakse usmjerene, paradoksalno, protiv života i osobnoga dostojanstva ljudskih bića. Dakle, ako bismo uistinu prihvatili prigovor da je Crkva licemjerna kada dopušta korištenje spornim cjepivima, a istodobno osuđuje zlo pobačaja, onda bismo, moralnoga integriteta i logičke koherentnosti radi, morali reći da je Crkva isto tako licemjerna kada jednako snažno i neupitno vrjednuje život djece dobivene umjetnom oplodnjom i one dobivene prirodnim putem, a $u$ isto vrijeme osuđuje umjetnu oplodnju kao moralno zlo.

Osim toga izvlačenje koristi iz nekih tuđih i prošlih nemoralnih djela obilježje je svijeta ranjenoga istočnim grijehom, naslijeđenim stanjem unutar kojega su vjernici pozvani odgovorno živjeti svoju osudenu slobodu. Zapravo, »naša je vlastita situacija slobode na neotklonjiv način suoblikovana tuđom krivnjom $\ll^{8}$. Koristeći se, kako to Karl Rahner kaže, banalnim primjerom: Znači li kupovanje banana podršku praksi izrabljivanja i potplaćenoga rada njihovih berača; podržava li se kupovinom banana ta socijalna nepravda i stoljetna trgovačka politika? ${ }^{9}$ Drugim riječima, ljudska je povijest ispunjena nepravdom i zločinima i upravo je ta nepravedna povijest prostor naše zauzetosti, uvjet našega egzistiranja. Zahtjev da sve današnje koristi budu oslobođene od svakoga nemoralnoga i nepravednoga djelovanja u prošlosti bio bi utopistički visok standard, ${ }^{10}$ koji bi, zapravo, onemogućio bilo kakvu ozbiljnu zauzetost u svijetu. ${ }^{11}$ Dakle dopustiti korištenje cjepivima izrađenim uz pomoć fetalnih tkiva ne znači odobriti pobačaj onda kada se ima koristi od njega. Na isti način kao što i preporuka doniranja organa umrlih, kao iznimnoga znaka ljubavi prema bližnjemu, ne znači odobravanje smrti donora, bilo prirodne, nesretne ili pak one izazvane nasilnim putem.

\section{Skandal izazvan korištenjem spornim cjepivima}

Što se tiče skandala, odnosno sablazni, nužno je reći da su vjernici dužni izbjeći, kada je god to moguće i kada to dobro bližnjega traži, svaku naznaku sablazni. U

\footnotetext{
${ }^{7}$ Usp. PONTIFICIA ACCADEMIA PER LA VITA, Nota circa l'uso dei vaccini.

${ }^{8}$ K. RAHNER, Temelji kršćanske vjere. Uvod u pojam kršćanstva, Rijeka, 2007., 152.

${ }^{9}$ Usp. isto, 152.

${ }^{10}$ Usp. E. J. FURTON, Vaccines Originating in Abortion, u: Ethics \& Medics 24(1999.)3, 3-4., ovdje 3.

${ }^{11}$ Usp. Z. MAROS, Moralno načelo suradnje u zlu, 201-202.
} 
moralnom nauku sablazan (scandalum) je grijeh koji se izravno protivi nutarnjoj naravi ljubavi prema bližnjem jer mu se predstavlja kao $\gg$ zamka na putu spasenja ${ }^{12}$. Sablazan je navođenje nekoga na grijeh ili izazivanje zabune oko toga što je grijeh, što se ostvaruje kroz izravni ili neizravni utjecaj na drugoga. Izravni utjecaj (scandalum directum) realizira se onda kada netko svojim djelovanjem ili ponašanjem u promatraču svjesno i željeno izaziva zabludu (navodi ga na grijeh); a indirektni utjecaj (scandalum indirectum) ostvaruje se onda kada promatrač sam zaluta (sagriješi) promatrajući ponašanje druge osobe, bez obzira na to je li on to ponašanje pravilno ili pogrješno protumačio. ${ }^{13}$

Moglo bi se reći da bi vjernici koji se koriste cjepivima mogli izazvati skandal kod onih vjernika koji nisu dobro poučeni u materiji, te stoga u primanju cjepiva vide ne samo strašno i očito licemjerje nego i teški grijeh. To bi one vjerski nepoučene $i$ one skrupulozne savjesti zbilja moglo dovesti u veliku duhovnu opasnost. ${ }^{14}$ Upravo zbog te duhovne opasnosti za druge vjernicima ostaje stroga dužnost izbjegavanja skandala kad je god to moguće, čak i onda kada bi to izbjegavanje značilo uskratiti sebi neka fizička dobra ili radosti koje proizlaze iz određenoga djelovanja. »Kršćanin mora dakle biti spreman znatno ograničiti svoju slobodu ponašanja ako vidi da njegovo, po sebi, dobro ponašanje postaje bližnjemu povod duhovne propasti. ${ }^{15}$

Međutim, budući da je primanje cjepiva u sebi dobro i budući da nema grijeha ako nema formalnoga pristanka na zlo pobačaja, u tom slučaju vjernici koji primaju cjepiva ne pružaju skandal drugima, nije dakle na djelu skandal koji je izravno dan, nego eventualno onaj skandal koji je neizravno izazvan, i to tuđim pogrješnim tumačenjem. Oni koji moralna načela shvaćaju životno ozbiljno poduzet će sve razumne korake kako bi izbjegli čak i onaj skandal koji je, zapravo, rezultat tuđega pogrješnoga shvaćanja. No unatoč tomu nisu na to obvezatni onda kada postoje ozbiljni, proporcionalni razlozi za (ne)djelovanje. Osim toga spriječiti mogućnost nečije pogrješne interpretacije tuđega ponašanja, odnosno spriječiti mogućnost neizravnoga skandala, često je nemoguće, kao što je nemoguće osobno biti odgovoran za racionalizacije drugih osoba. ${ }^{16}$

\footnotetext{
${ }^{12}$ B. HÄRING, Kristov zakon, II, Prvi dio posebne moralne teologije, Zagreb, 1980., 491.

${ }^{13}$ Usp. isto, 490-491.; A. GÜNTHÖR, Chiamata e risposta. Una nuova teologia morale - III, Milano, 1988., 368.

${ }^{14}$ Usp. Z. MAROS, Moralno načelo suradnje u zlu, 209.

${ }^{15}$ B. HÄRING, Kristov zakon, II, 493.

${ }^{16}$ Usp. D. P. MAHER, Vaccines, Abortion and Moral Coherence, The National Catholic Bioethics Quarterly 2002., 51-67., ovdje 64-65. Dostupno na: https://www.immunize.org/talking-aboutvaccines/maher.pdf (1. 10.2020.).
} 


\section{Fetalne stanične linije is njima povezan pobačaj}

Izbjegavanje sudjelovanja u zlu, kao i svakoga oblika skandala, teološki se opravdava i teškim posljedicama koje određeno djelovanje može prouzročiti. U tom konkretnom slučaju to bi bila sumnja koju i sama Deklaracija iznosi kad govori o dužnosti inzistiranja na alternativnim cjepivima. Naime, uz spomenuti skandal, pristanak na sporna cjepiva bez prethodnoga protivljenja i pritiska mogao bi, premda ne nužno, potaknuti nove pobačaje. ${ }^{17}$ Moglo bi se dogoditi da se ženama koje se još uvijek slamaju odlukom o pobačaju ta odluka olakša nekim eventualnim dobrom koje može proizići iz pobačaja (stvaranje cjepiva koja spašavaju druge živote), što bi, iako malo moguće, ipak moglo postati motivirajući čimbenik koji doprinosi odluci o pobačaju. No, kako to tumači Daniel P. Maher, čak i kada bi neka žena u svojoj odluci o pobačaju bila motivirana, odnosno ohrabrena mogućnošću nekoga eventualnoga dobra iz toga čina, to ne bi predstavljao ništa više nego način ublažavanja sumnje u donošenju odluke ili pak puka racionalizacija, za koju drugi, kako je već rečeno, ne može biti odgovoran. ${ }^{18}$

U pokušaju racionalne obrane cjepiva neki su osporili tu mogućnost da će sadašnji pristanak na cjepiva iz postojećih staničnih linija eventualno potaknuti buduće pobačaje radi stvaranja novih staničnih linija namjernim pobačajima. Potvrđujući tragičnost činjenice da su stanične linije WI-38 i MRC-5 izvedene iz tkiva pobačenih ljudskih bića, govore kako su ta nemoralna djelovanja zapravo bila jednokratni događaji završeni davno u povijesti. Osim toga ističe se da su postojeće fetalne linije ne samo već dobro znanstveno utvrđene nego i dostatne za buduću proizvodnju (jer su praktički beskonačne), stoga postoji malo znanstvenoga poticaja za izradu novih staničnih linija novim pobačajima. ${ }^{19}$ Čini se da i novije izjave crkvenoga autoriteta aludiraju bilo na vremensku udaljenost pobačaja bilo na jednokratnost tih događaja kada navode da su stanične linije na kojima su cjepiva temeljena dobivene »isključivo iz dvaju fetusa « pobačenih šezdesetih godina prošloga stoljeća. ${ }^{20}$ No postoje naznake koje upućuju ne samo na neodrživost teze o nepostojanju znanstvenoga poticaja za izradu novih staničnih linija nego i na neutemeljenost izjave o samo dvama pobačajima.

\footnotetext{
${ }^{17}$ Usp. PONTIFICIA ACADEMIA PRO VITA, Dichiarazione, 4-5.

${ }^{18}$ Usp. D. P. MAHER, Vaccines, Abortion and Moral Coherence, 65.

${ }^{19}$ Usp. E. J. FURTON, Vaccines Originating in Abortion, 3-4.; D. P. MAHER, Vaccines, Abortion and Moral Coherence, 59.

${ }^{20}$ Usp. PONTIFICIA ACCADEMIA PER LA VITA, Nota circa l'uso dei vaccini; SALA STAMPA DELLA SANTA SEDE, Nota della Congregazione per la dottrina della Fede sulla moralità dell'uso di alcuni vaccini anti-Covid-19, 1-2.
} 
Naime već na čistoj racionalnoj razini, imajući u vidu sav tehnološki napredak i njegov znanstveni imperativ neprestanoga usavršavanja, teško je prihvatljivo da će se znanstveni um zadovoljiti već postojećim te da ne će tražiti nove, bolje, produktivnije poticaje, načine i mogućnosti. Možda će znanost zbilja dovesti do prestanka korištenja tim stanicama ili pak do prestanka izvođenja novih stanica putem novih pobačaja - recimo, stvaranjem isključivo sintetičkih cjepiva - no do sada postojeća praksa i do sada stvorene stanične linije (poput: WI-38, MRC-5, HEK-293, PER C6, WI-26 VA4 $)^{21}$ osporile su navedene teze.

Na primjer u znanstvenom članku koji su zajednički objavili tvorci recentne kineske fetalne stanične linije referentnoga koda Walvax-2, izrađene 2015. godine, autori u završnoj raspravi članka donose i usporednu razliku različitih kriterija između stanične linije MRC-5 i novouspostavljene Walvax-2 te zaključuju da tamo gdje se Walvax-2 ne pokazuje superiornim u odnosu na MRC-5 onda barem pokazuje jednake karakteristike staničnoj liniji MRC-5. ${ }^{22}$ Slijedeći logiku znanstvenoga istraživanja, zbilja je nezamislivo, jer bi bilo kontradiktorno imperativu napretka, da će budući znanstvenici stati na tim istraživanjima te da ne će pokušati napraviti nešto još superiornije od toga što je trenutačno dostupno, a zadovoljava potrebe za širu industrijsku proizvodnju. Osim toga i sami autori govore o određenim ograničenjima novonastale stanične linije ističući da su potrebna daljnja istraživanja kako bi se ta ograničenja smanjila ili eventualno uklonila. ${ }^{23}$ Dakle argument koji tvrdi da ne će biti novoga znanstvenoga poticaja za stvaranje novih fetalnih staničnih linija, a time i novih pobačaja, neodrživ je sa stajališta racionalne argumentacije, a i osporen je podatcima najnovije prakse.

Ista se spomenuta racionalna argumentacija može primijeniti i na tvrdnju da su za stvaranje WI-38 i MRC-5 urađena samo dva pobačaja. Naime teško je razumski vjerovati da su za prve u povijesti stvorene fetalne stanične linije, kada je znanstveni razvoj bio na neusporedivo nižem stupnju u odnosu na onaj danas, zbilja korištena samo dva pobačaja. U redovitim situacijama napredak je rezultat mnogih pokušaja, istraživanja, ispitivanja, usvajanja i opovrgavanja usvojenoga. Osim toga, ako je kineskim znanstvenicima u 2015. godini bilo potrebno devet (9) fetusa ${ }^{24}$ za uspješno

${ }^{21}$ Usp. NATIONAL CATHOLIC BIOETHICS CENTER, FAQ: on the Use of Vaccines, 2006. Dostupno na: https://www.ncbcenter.org/resources-and-statements-cms/faq-on-the-use-of-vaccines (26.9. 2020.).

${ }^{22}$ Usp. B. MA i dr., Characteristics and viral propagation properties of a new human diploid cell line, walvax-2, and its suitability as a candidate cell substrate for vaccine production, $\mathrm{u}$ : Human Vaccines \& Immunotherapeutics 11(2015.)4, 998-1009., ovdje 1006. Dostupno na: https://www.ncbi.nlm. nih.gov/pmc/articles/PMC4526020/ (1. 10.2020.).

${ }^{23}$ Usp. B. MA i dr., Characteristics and viral propagation..., 1005-1006.

${ }^{24}$ Usp. isto, 999. 
uspostavljanje visokokvalificirane fetalne stanične linije koja zadovoljava kriterije za masovnu proizvodnju cjepiva, nezamislivo je, usudili bismo se reći nemoguće, da je šezdeset godina unazad takav postupak, a prvi u povijesti, zahtijevao samo dva fetusa.

Premda je istina da su spomenute WI-38 i MRC-5 u konačnici izvedene iz samo dvaju pobačaja, ipak, istraživanja pokazuju kako je urađeno daleko više pobačaja kako bi se stekla tehnička stručnost potrebna za razvoj tih staničnih linija. ${ }^{25}$ Rene Leiva donosi podatak da je Leonard Hayflick 1961. godine prvi put objavio rad koji opisuje dvadeset i pet humanih diploidnih staničnih linija označenih od WI-1 do WI-25. Sve su izdvojene iz različitih organa devetnaest odvojenih pobačenih fetusa, a svrha odabira različitih organa bila je testirati razliku tkivnih karakteristika. ${ }^{26}$ Osim toga Leiva donosi podatak da postoje dokumentirani izvori koji pokazuju da je za izradu cjepiva protiv rubeole (RA 27/3) korišteno najmanje osamdeset pobačaja, premda, kako kaže, postoje naznake da ih je bilo i više. ${ }^{27}$

\section{Komercijalizacija, industrija i zloporaba fetalnih staničnih linija}

Iza bojazni da bi se moglo potaknuti buduće pobačaje stoji problematika koja seže mnogo dalje i šire od samoga čina pobačaja. Riječ je o svojevrsnoj komercijalizaciji fetusa, zbiljskoj industriji fetalnoga tkiva. Moralni standard za postupanje prema leševima fetusa Crkva je navela u instrukciji Donum vitae, u kojoj ističe da je zabranjena bilo koja trgovina leševima fetusa, isto kao i u slučaju leševa odraslih osoba, te da »leševe zametaka ili ljudskih plodova, bilo da su namjerno ili pak nenamjerno pobačeni, treba poštivati jednako kao i smrtne ostatke drugih ljudskih bića $\ll^{28}$. Dakle Katolička Crkva načelno se ne protivi korištenju fetalnoga tkiva ili pak njegovu presađivanju (kao na koncu i kod odraslih) ako nema nikakve zlouporabe, komercijalizacije i ako se spašava temeljno poštovanje prema umrlima. Međutim ta se praksa smatra opasnom te bi bilo poželjno izbjegavati ju svaki put kada je to mo-

${ }^{25}$ Usp. R. LEIVA, A Brief History of Human Diploid Cell Strains, u: The National Catholic Bioethics Quarterly 2006., 443-451., ovdje 444. Dostupno na: https://www.pdcnet.org/ncbq/content/ ncbq_2006_0006_0003_0443_0451 (9. 10.2020.); M. WADMAN, Medical research: Cell division, u: Nature 498(2013.) 27, $4 \overline{2} 2-426$. ovdje 423.

${ }^{26}$ Usp. R. LEIVA, A Brief History of Human Diploid Cell Strains, 444.

${ }^{27}$ Usp. isto, 450. No sam naziv cjepiva RA 27/3, znači: »Rubella abortus, twenty-seventh fetus, third tissue extract «. Usp. isto, 447. A popis svih fetalnih linija, zajedno sa specifikacijom spola i vremena trudnoće fetusa čije su stanice tada korištene, dostupan je na mrežnoj stranici: CHILDREN OF GOD FOR LIFE, Aborted Fetal Material Used in Vaccines and Medicines. Dostupno na: https:// cogforlife.org/wp-content/uploads/AbortedFetalCellLines.pdf (24. 10. 2020.).

${ }^{28}$ ZBOR ZA NAUK VJERE, Donum Vitae. Dar života. Naputak o poštivanju ljudskog života u nastanku i o dostojanstvu rađanja. Odgovori na neka aktualna pitanja, Zagreb, 1997., I, 4. 
guće. Izražava se bojazan da bi ta praksa korištenja pobačenim fetusima vjerojatno institucionalizirala praksu pobačaja za terapeutske svrhe, odnosno za zdravstvenu zaštitu. Ako bi medicinska zaštita i njezina terapeutska svrha stvorili svojevrsnu ovisnost o pobačenim fetusima, onda bavljenje tim zanimanjima i korištenje medicinskom pomoći zbilja ne bi bilo u moralnom suglasju s načelnim protivljenjem pobačaju. ${ }^{29}$

To implicira da pristanak na korištenje spornim cjepivima, iako je moralno dopustiv u određenim slučajevima (a ponekad i nužan ${ }^{30}$ ), ipak nije bez određenih rizika koji bi mogli dovesti u pitanje moralni integritet, odnosno moralnu koherentnost. Osim toga, taj pristanak na određen način uključuje daljnje izazove. Izazov će biti odgovoriti na određena pitanja koja nisu lišena temeljne racionalnosti. Recimo, ako se s određenom lakoćom i moralnom opuštenošću pristaje na spomenutu praksu korištenja već pobačenim fetusima, ako se prošlo zlo može opravdati sadašnjom koristi, zašto se protiviti sadašnjim pobačajima radi buduće koristi? Ili, kako opravdati dopuštenost uporabe sadašnjih postojećih staničnih linija s jedne strane, a s druge potpunu zabranu komercijalizacije fetalnih tkiva za bilo koju drugu dobrobit? ${ }^{31}$

Premda se, sa stajališta morala, odgovor nudi u razlici između formalnoga, neposrednoga materijalnoga i daljega posrednoga materijalnoga sudjelovanja, ${ }^{32}$ ipak postaje sve teže tu razliku braniti u široj javnosti. Naime, kako se praksa istraživanja i korištenja fetalnim tkivom sve više proširuje, postoji opasnost da se argumenti koji se danas koriste za odobravanje korištenja cjepivima preoblikuju za opravdanje novih nehumanih praksi, koje se, zapravo, i događaju unatoč različitim zakonskim okvirima i pravilima regulatornih tijela. Naime regulacija upotrebe fetusa i fetalnoga tkiva počela je između 1969. i 1973. godine. Brojni etičari i različita regulatorna tijela univerzalno inzistiraju na tome da u razvoju virusnih cjepiva iz pobačenoga fetalnoga tkiva ne smije doći do dogovora između žene koja je odlučila pobaciti, odnosno liječnika koji rade pobačaj i samih istraživača ili proizvođača cjepiva. Odnosno zabranjuje se da oni koji uzimaju fetalno tkivo imaju bilo koji udio u vremenu, metodi ili postupcima kojima se koristi za prekid trudnoće. Isto tako traži se da liječnici koji obavljaju pobačaj ne odstupaju od uobičajene metode pobačaja samo kako bi mogli pružiti optimalno fetalno tkivo za istraživače cjepiva. ${ }^{33}$

\footnotetext{
${ }^{29}$ Usp. D. P. MAHER, Vaccines, Abortion and Moral Coherence, 63.

${ }^{30}$ Usp. PONTIFICIA ACADEMIA PRO VITA, Dichiarazione, 8., bilješka br. 15.

${ }^{31}$ Usp. D. P. MAHER, Vaccines, Abortion and Moral Coherence, 67.

${ }^{32} \mathrm{Za}$ distinkciju sudjelovanja u zlu vidi: Z. MAROS, Moralno načelo suradnje u zlu, 202-206.

${ }^{33}$ Usp. D. P. MAHER, Vaccines, Abortion and Moral Coherence, 58.; NEBRASKA COALITION ETHICAL RESEARCH, The Ethics of the Walvax-2 Cell Strain. Dostupno na: http://ethicalresearch.net/positions/the-ethics-of-the-walvax-2-cell-strain/ (11.10. 2020.).
} 
Iako se navedena pravila ne mogu primijeniti na slučaj stvaranja prvih fetalnih staničnih linija (WI-38, kao i MRC 5), što zbog nedostatka i manjkavosti podataka, što zbog nepostojanja regulatornih pravila u to vrijeme, ipak postoje neke naznake da je postojala namjera u činu korištenja pobačajem upravo za stvaranje staničnih linija. ${ }^{34}$ Osim toga i suvremena praksa pokazuje da su pravila regulatornih tijela samo neki fantomski okvir formalnosti koji se traži kako bi sustav prividno funkcionirao. Naime u slučaju stvaranja Walvax-2 ne samo da se koristilo posebnim pobačajnim sredstvom (metodom vrećice $s$ vodom) kako bi se dobili netaknuti svježi organi nego je, prema svemu sudeći, postojao i tijesni dogovor između onih koji su pobačaj radili i roditelja koji su na to pristali. ${ }^{35}$ Naime, kako sami tvorci te linije navode, da bi se osigurala visoka kvaliteta stanične linije, prije same izrade napravljeni su strogi i sveobuhvatni kriteriji koji su se odnosili na određenu gestacijsku dob fetusa, korištenje posebnim vrstama pobačaja, rigoroznu provjeru karijere i anamneze roditelja. ${ }^{36}$ Moguće je, premda ne nužno, da su slični kriteriji postojali (i postoje) i kod izvođenja ostalih staničnih linija. No ta tvrdnja ipak ostaje samo na razini mišljenja jer bi za njezinu znanstvenu potvrdu ipak bilo potrebno daljnje, detaljnije i pojedinačno istraživanje svih postojećih fetalnih staničnih linija.

Do koje mjere je otišlo nepoštovanje postojećih zakona i pravila regulatornih tijela o korištenju fetusima i fetalnim tkivima za različite svrhe zorno prikazuje Izvješće Odbora za pravosude, Senata Sjedinjenih Američkih Država. To Izvješće na 547 stranica donosi oko 20 tisuća dokumenata, ugovora, faktura, proračuna, internih zdravstvenih standarda i vodiča, police tehničkih kompenzacija, koje je spomenuti Odbor prikupio u postupku istraživanja različitih kriminalnih praksi organizacija uključenih u transfer fetalnih tkiva dobivenih pobačajem. Samo jedan primjer fetalne nabave i distribucije tkiva tvrtke Advanced Bioscience Resources (ABR) okvirno pokazuje poslovni model svih organizacija uključenih u industriju fetalnoga tkiva, a koje su bile predmet spomenute istrage. U lipnju 2014. godine tehničar ABR tvrtke nabavio je fetus star 20 tjedana od klinike za planirano roditeljstvo (Planned Parenthood) koji je toj klinici platio 60 dolara. Pojedinačne organe i tkiva toga fetusa tvrtka $A B R$ različitim kupcima naplaćivala je u iznosu od 325 dolara (mozak, pojedinačno oba oka, dio jetre, timus, oba plućna krila), a zasebno su naplaćeni troškovi za otpremu i pregled tkiva. Dakle od toga jednoga fetusa, kupljenoga za 60 dolara, ABR je naplatio svojim kupcima ukupno 2275 dolara za uzorke tkiva te uz to dodatne odvojene naknade za otpremu i pregled tkiva na bolesti. Prema

\footnotetext{
${ }^{34}$ Usp. R. LEIVA, A Brief History of Human Diploid Cell Strains, 450.

${ }^{35}$ Usp. NEBRASKA COALITION ETHICAL RESEARCH, The Ethics of the Walvax-2 Cell Strain.

${ }^{36}$ Usp. B. MA, L. F. HE i dr., Characteristics and viral propagation ..., 18.
} 
spomenutom Izvješću, isti poslovni model primjenjuju i druge institucije upletene $\mathrm{u}$ industriju fetalnoga tkiva. ${ }^{37}$

\section{Prigovor savjesti i etički neupitna cjepiva}

Upravo zbog eventualne mogućnosti novih pobačaja i spomenute komercijalizacije fetusa povezane s njima, ali i zbog lakoće kojom puka materijalna suradnja može prijeći u istinsku formalnu ${ }^{38}$ (ako se, među ostalim, izgubi svijest o moralnom zlu pobačaja), zahtijeva se pružanje otpora spomenutim cjepivima, pa i kroz priziv savjesti. Zapravo, iako same buduće moguće zlouporabe ne čine upotrebu postojećih cjepiva nemoralnom, ipak, nedostatak adekvatnoga prosvjeda, kao i neinzistiranje na proizvodnji alternativnih cjepiva, može pridonijeti određenom moralnom kompromisu u toj nimalo jednostavnoj stvarnosti. To može potaknuti opravdavanje pobačaja kroz iluziju o njegovoj koristi jer se navodnim dobrom koje se iz pobačaja ostvaruje još navodnije umanjuje njegova težina. ${ }^{39}$

Odbijanje cijepljenja zbog priziva savjesti mogao bi biti jedan oblik onoga zakonitoga pritiska koji su vjernici dužni činiti kako bi se proizvodila etički neupitna cjepiva. Ako bi postojao dovoljan broj ljudi koji bi odbio ta cjepiva, ako bi se proširilo javno protivljenje, onda bi proizvođači možda bili primorani proizvoditi ona koja ne će biti povezana s pobačajem. ${ }^{40}$ Taj zahtjev implicira da postoje načini da se stanične linije izvedene iz fetusa zamijene nekim alternativnim stanicama iz humanoga i ne-humanoga tkiva, a nijedan od njih ne bi uključivao uništavanje ljudskih bića. ${ }^{41}$ Recimo, izrada cjepiva na bazi staničnih podloga poput embrija pilića, stanica afričkoga majmuna i stanica kineskoga hrčka mogla bi biti alternativa. Osim toga alternativna cjepiva mogu se raditi i pomoću rekombinantne DNK tehnologije ${ }^{42}$ ili pak upotrebom fetusnih stanica dobivenih amniocente-

\footnotetext{
${ }^{37}$ Usp. COMMITTEE ON THE JUDICIARY UNITED STATES SENATE, Human Fetal tissue Research. Context and Controversy, Washington, 2016., 2-4. Dostupno na: https://www.grassley.senate. gov/sites/default/files/judiciary/upload/22920\%20-\%20FTR.pdf (5. 10.2020.). Kako to Izvješće na istim stranicama donosi, tehničar tvrtke $A B R$ za jedan dan, odnosno u roku od četiriju sati, obradio je i otpremio ukupno 20 uzoraka tkiva od četiriju različitih fetusa koje je dobio od klinike Planned Parenthood (Planirano roditeljstvo). Svojim je kupcima ABR naplatio ukupne naknade u iznosu od 6825 dolara samo za uzorke iz četiriju fetusa koje su klinici Planned Parenthood platili 240 dolara. Usp. isto.

${ }^{38}$ Usp. Z. MAROS, Moralno načelo suradnje u zlu, 209.

${ }^{39}$ Usp. NATIONAL CATHOLIC BIOETHICS CENTER, FAQ: on the Use of Vaccines.

${ }^{40}$ Usp. Usp. E. J. FURTON, Vaccines Originating in Abortion, 4.

${ }^{41}$ Usp. NEBRASKA COALITION ETHICAL RESEARCH, The Ethics of the Walvax-2 Cell Strain.

${ }^{42}$ Usp. R. LEIVA, A Brief History of Human Diploid Cell Strains, 451.
} 
zom. ${ }^{43}$ Korištenje takvim i sličnim alternativnim izvorima za izradu virusnih cjepiva ne samo da bi otklonilo uistinu mučne i nezahvalne moralne dvojbe nego bi i razotkrilo postojeće populističke predodžbe kojima se uporabom fetusa u izradi cjepiva na određen način pobačaj iskupljuje ili pak one da je pobačeno fetalno tkivo jedini izvor za proizvodnju virusnih cjepiva. ${ }^{44}$

Pojedinci bi dakle zbog priziva savjesti mogli odbiti upotrebu cjepiva, ali pod pretpostavkom da bi mogli pronaći odgovarajuće načine zaštite sebe i drugih od bolesti. ${ }^{45}$ Međutim problem priziva savjesti javlja se kada su uključena djeca. Roditelji su odgovorni za zaštitu djece te sprječavanje da ona budu izvor zaraze širem društvu. ${ }^{46}$ Roditelji dakle imaju društvenu i moralnu dužnost i obvezu osigurati život i zdravlje svoje djece, što govori da je mogućnost priziva savjesti u kontekstu cijepljenja individualna jer svatko snosi drukčiju vrstu i oblik odgovornosti. ${ }^{47}$

Dakle priziv savjesti posebno je problematičan za roditelje onda kada konkretne posljedice toga priziva snose djeca. $U$ tom slučaju priziv savjesti ulažu odrasli, ali se on bitno odnosi na djecu, njihove vršnjake, školske drugove i prijatelje, koji se necijepljenjem izlažu ozbiljnom riziku od zaraze, čime se, među ostalim, krši njihovo pravo na otvorenu budućnost. ${ }^{48}$ Premda, recimo, američki Vrhovni sud nikada nije

${ }^{43}$ Usp. M. WADMAN, COVID-19 Vaccines that use human fetal cells draw fire. Abortion opponents urge United States and Canada to avoid 'ethically-tainted' cell lines, Science 368(2020.), 11701171. Dostupno na: https://science.sciencemag.org/content/368/6496/1170 (19.9. 2020.).

${ }^{44}$ Usp. NEBRASKA COALITION ETHICAL RESEARCH, The Ethics of the Walvax-2 Cell Strain. Prema korištenim autorima, neka od alternativnih cjepiva već postoje. Naime američka Federalna agencija za hranu i lijekove (FDA) licencirala je cjepiva protiv zaušnjaka i ospica koja se proizvode iz staničnih supstrata uzetih iz embriona pilića. Usp. NEBRASKA COALITION ETHICAL RESEARCH, The Ethics of the Walvax-2 Cell Strain; E. J. FURTON, Vaccines Originating in Abortion, 3.

${ }^{45}$ SALA STAMPA DELLA SANTA SEDE, Nota della Congregazione per la dottrina della Fede sulla moralità dell'uso di alcuni vaccini anti-Covid-19.

${ }^{46}$ Usp. D. P. MAHER, Vaccines, Abortion and Moral Coherence, 65-66. Djeca se cijepe u vrlo ranoj dobi. Na primjer cjepivo protiv rubeole daje se u dobi između 12 i 15 mjeseci, s kasnijim pojačivačima. Ako nije cijepljeno, dijete može razviti razne ozbiljne komplikacije, kao što je encefalitis koji inficira 1 od 1000 do 2000 žrtava rubeole. Značajan postotak njih također će pretrpjeti trajno oštećenje mozga ili smrt. Jasno je da roditelji riskiraju kada odbiju imunizirati dijete. Usp. E. J. FURTON, Vaccines Originating in Abortion, 4.

${ }^{47}$ Usp. E. J. FURTON, Vaccines Originating in Abortion, 4.

${ }^{48}$ Usp. M. L. LO GIACCO, Il rifiuto delle vaccinazioni obbligatorie per motivi di coscienza. Spunti di comparazione, Stato, Chiese e pluralismo confessionale, 2020., 41-65., ovdje 42., 52. Dostupno na: https://www.statoechiese.it/images/uploads/articoli_pdf/Lo_Giacco.M_Il_rifiuto.pdf?pdf=ilrifiuto-delle-vaccinazioni-obbligatorie-per-motivi-di-coscienza.-spunti (10. 12. 2020.). 
izravno intervenirao u svezi s pitanjem vjerski utemeljenih izuzeća od cijepljenja, ipak je u više navrata proglasio legitimitet obveze cijepljenja. Budući da je cijepljenje važno i funkcionalno u zaštiti javnoga zdravlja i sigurnosti, presuda iz 1944. godine donosi da pravo na slobodno prakticiranje vjere ne uključuje slobodu izlaganja zajednice ili djeteta šteti, bolesti ili smrti uslijed epidemije. ${ }^{49}$

Pitanje prigovora savjesti u konkretnom slučaju cijepljenja čini se prilično složenim i iz drugih razloga. Ne samo jer je inače teško odrediti kriterije za katalogiziranje prigovora savjesti $\mathrm{i}^{50}$ nego i zbog činjenice da prigovor savjesti počiva na određenim vrijednostima koje prigovor želi zaštititi ili potvrditi, a te vrijednosti nisu univerzalne, nego odgovaraju samoj pluralnosti društva. Dakle, ako se u pitanju cijepljenja uzme važećim prigovor savjesti, onda velik dio različitih vjerskih skupina može odbiti cijepljenje. Židovi i muslimani jer sadrži supstancije svinjskoga podrijetla, scijentistička crkva jer predstavlja narušavanje Božjega plana, đainizam jer se cjepivom ubija nešto živo (bakterije i virusi), amiši jer odbacuju sve aspekte modernoga doba, a i neke reformirane zajednice za koje cijepljenje predstavlja nedostatak vjere u božansku providnost. ${ }^{51}$

Dakle problem prigovora savjesti u pluralističkom društvu može lako skrenuti u određeni stupanj patologije jednake patologiji ljudskih prava. ${ }^{52}$ Drugim riječima, ako svaki individualni zahtjev ili interes postane ljudsko pravo, na kraju ćemo obezvrijediti samu kategoriju temeljnih prava do mjere izravnavanja vrijednosti. $\mathrm{Na}$ isti način, ako se prigovor savjesti fragmentira do te mjere da se svodi na različitost mišljenja, odnosno da se njime pruža otpor i za neka usmjerenja sekundarne ili pak političke prirode, postoji opasnost da se on liši onoga dostojanstva i važnosti koji čine samu srž prigovora savjesti. ${ }^{53}$

${ }^{49}$ Usp. isto, 49-50.

${ }^{50}$ Usp. C. CARDIA, Tra il diritto e la morale. Obiezione di coscienza e legge, Stato, Chiese e pluralismo confessionale, 2009., 1-29., ovdje 4. Dostupno na: https://www.statoechiese.it/images/ uploads/articoli_pdf/cardia_traildiritto.pdf?pdf=tra-il-diritto-e-la-morale.-obiezione-di-coscienzae-legge (12. 1. 2021.).

${ }^{51}$ Usp. M. L. LO GIACCO, Il rifiuto delle vaccinazioni obbligatorie per motivi di coscienza, 44-49.

${ }^{52}$ Carlo Cardia u bilješci br. 2 tumači kako od bioetike do ekologije, od svemirskoga do vojnoga prostora, od medicine do turizma ne postoji situacija ili stanje u kojem se ne mogu identificirati ona ljudska prava potrebna za dobrobiti pojedinca ili zajednice. Međutim taj, zapravo, beskraj širenja repertoara temeljnih prava vodi riziku u kojem sama kategorija ljudskih prava gubi važnost. Jer ako se koncept ljudskoga prava poistovjećuje s bilo kojom ljudskom legitimnom tvrdnjom, onda se pravo identificira s ljudskom potrebom, čime se postavlja neporeciva aporija: $\gg$ Ako je sve temeljno, ništa nije temeljno. $\ll$ C. CARDIA, Tra il diritto e la morale, 3.

${ }^{53}$ Usp. C. CARDIA, Tra il diritto e la morale, 2-3. 


\section{Vrijednost i nepovredivost ljudskoga života}

Budući da su zdravstvene koristi cjepiva važne, razlozi za odbijanje cjepiva moraju imati istu jačinu i važnost. »Daljnja šteta korištenja cjepivom nije ni neposredna ni nužna, a ne postiže se neko nužno očito dobro odbijajući ga. ${ }^{54}$ No, iako buduće eventualne zlouporabe današnjega pristanka na cjepivo nisu presudne i nužne niti idu na savjest korisnika cjepiva, evidentno je da nisu nevažne te da imaju određenu i teološku, ali i društvenu težinu. Naime moralna bi neosjetljivost lako mogla ne samo opravdati nego i nerazborito olakšati i promicati mnoge nehumane prakse. ${ }^{55}$ Gubitkom moralnoga osjećaja za vrijednost, svetost i nepovredivost ljudskoga života otvara se prostor različitim nehumanim zlouporabama čiji razmjer u budućnosti već postojeće zlouporabe mogu nagovijestiti, ali se ne čini vjerojatnim da ih mogu spriječiti. Gdje će se čovječanstvo zaustaviti, gdje će staviti granicu koju ne smije prijeći, ako ljudski život izgubi apsolutnu vrijednost, nepovredivo dostojanstvo i neusporedivu svetost? No upravo zbog apsolutne vrijednosti dostojanstva tudih života bilo bi nehumano i neodgovorno osuditi cjepiva i cijepljenje, s obzirom na zdravstveni učinak koji imaju. Ali iz istoga razloga apsolutne vrijednosti dostojanstva tuđih života bilo bi jednako nehumano i neodgovorno pristajati na njih bez ikakve moralne neugode i time, eventualno, podržavati skandal povrede ljudskoga života o kojem Crkva neumorno govori. ${ }^{56}$

Iz navedenih razloga proizlazi dužnost inzistiranja na proizvodnji alternativnih cjepiva. Izostanak toga inzistiranja prisiljava liječnike, roditelje, korisnike cjepiva na izbor između dvije jednako neodržive mogućosti: ili djelovati protiv vlastite savjesti ili se ne cijepiti. Stoga skandal nije, kako to Edward J. Furton donosi, što Crkva dopušta uporabu tih cjepiva kao ekstremnu mjeru nakon što je sve prije pokušano. Skandal je što država, znanstvenici, istraživački timovi ne poštuju jednako savjest svih građana, moralna uvjerenja milijuna ljudi i ne osiguravaju im jednaku nužnu medicinsku skrb, prisiljavajući ih na nimalo jednostavne izbore. ${ }^{57}$

\section{Zaključak}

Situacija izazvana pandemijom bolesti COVID-19 izazvala je mnoštvo kontradiktornosti, socijalnoga nezadovoljstva, nesnalaženja i nerazumijevanja. Jedno od njih je i sastav cjepiva protiv bolesti COVID-19, s kojima je cijepljenje već započeto.

\footnotetext{
${ }^{54}$ D. P. MAHER, Vaccines, Abortion and Moral Coherence, 66.

${ }^{55}$ Usp. isto.

${ }^{56}$ Usp. ZBOR ZA NAUK VJERE, Donum Vitae, I, 4; IVAN PAVAO II., Evangelium Vitae - Evandelje života. Enciklika o vrijednosti i nepovredivosti ljudskog života, Zagreb, 1995., br. 4.

${ }^{57}$ Usp. E. J. FURTON, Vaccines Originating in Abortion, 4.
} 
Naime neka od cjepiva kao biološkim materijalom koriste se fetalnim staničnim linijama dobivenim iz dobrovoljnih pobačaja. Već je dobro poznato da Crkva pobačaj smatra velikim društvenim zlom i teškim grijehom te da je radikalna i neumoljiva po pitanju obrane nepovredivoga dostojanstva ljudske osobe. No ni približno nije bio poznat njezin stav o moralnoj dopuštenosti korištenja spornim cjepivima, sudeći barem po reakcijama naše šire javnosti. Moralna dopuštenost korištenja cjepivima povezanim s pobačajem izazvala je različite prigovore, poput onoga da je Crkva s tim stavom pokazala vrhunac licemjerja, kao i vrhunac kontradiktornosti svoga nauka. Naime kako se može, moralnoga i intelektualnoga integriteta radi, oštro suprotstavljati pobačaju, a u isto vrijeme opravdati ga onda kada se ima korist od njega? Hoće li to dopuštenje izazvati sablazan i hoće li potaknuti buduće pobačaje od kojih bi se mogla imati neka korist?

Iz priloga je jasno da ta dopuštenost ne znači legitimiziranje pobačaja, njegovo odobravanje, kao što kupovanje banana ne znači legitimiziranje izrabljivačkoga rada onih uključenih u njihovo branje. Isto tako vidjeli smo da korištenje tim cjepivima ne znači izazivanje izravne sablazni, što bi vjernicima bilo teško moralno zlo, nego eventualno one neizravne, za što vjernici ne mogu snositi moralnu odgovornost. No, budući da mogućnost izazivanja sablazni tim dopuštenjem ipak postoji, kao što i postoji mogućnost zlouporabe današnjih argumenata ili pak eventualnih budućih pobačaja i svih mogućih nehumanih praksi s njim povezanih, vjernicima ostaje stroga dužnost pružanja otpora spornim cjepivima, čak i prizivom savjesti onda kada je i ako je taj priziv moguć.

Dakle, iako ne postoji zabrana korištenja spornim cjepivima, iako sve buduće moguće zlouporabe ne idu na savjest korisnika cjepiva, ipak treba pružiti otpor svim pravednim sredstvima. To se traži ne samo zato što bi olako pristajanje na posrednu udaljenu materijalnu suradnju moglo prijeći u istinsku formalnu nego i što moralna lakoća pristupa stvara određeni društveni konsenzus o danas sve brojnijim povredama života i dostojanstva ljudskih bića. 


\section{ETHICAL PROBLEMS RELATED TO ALLOWING THE USE OF MORALLY QUESTIONABLE VACCINES}

\section{Zorica MAROS*}

Summary: When rubella vaccines came on the market in the 1960s, a socio-intellectual discussion about their ethical-moral dimension began. Namely, the use offetal tissue harvested from intentional abortions to make these vaccines makes them morally questionable. The Church has allowed end-users to use such vaccines if there is no other way of protection, that is, to achieve due wellbeing. Nevertheless, this permission has caused and still causes numerous objections, as well as great misunderstandings and disagreements. Can we talk about moral consistency and integrity if those who strongly oppose abortion agree to vaccines whose production is related to intentional abortion? Is the Church contradicting its teaching with this permission, or is it hypocritical? The article offers a theoretical reflection on specific disagreements to eliminate these intellectually and religiously in no way trivial misunderstandings.

Keywords: vaccine, Catholic Church, ethical issues, hypocrisy, scandal, appeal to conscience, commercialization of abortion.

* Assoc. Prof. Zorica Maros, Ph.D., Catholic Faculty of Theology, University of Sarajevo, Josipa Stadlera 5, 71000 Sarajevo, Bosnia and Herzegovina, maroszorica@gmail.com 